\title{
Uso de técnicas de geoprocessamento para caracterização geoambiental das áreas de ocorrência do patrimônio espeleológico no Geossistema Ferruginoso do Parque Nacional da Serra do Gandarela, Minas Gerais
}

\section{Use of geoprocessing techniques for the geoenvironmental characterization of the occurrence areas of speleological heritage in the Ferruginous Geosystem of the Serra do Gandarela National Park, Minas Gerais}

Darcy José dos Santos Mestre em Análise e Modelagem de Sistemas Ambientais, pela UFMG Analista Ambiental do Instituto Chico Mendes de Conservação da Biodiversidade, Centro Nacional de Pesquisa e conservação de Cavernas CECAV, Brasil darcymgsantos@hotmail.com

Úrsula Ruchkys

Doutora em Geologia pela UFMG. Professora adjunta do Departamento de Cartografia e do Programa de pós-Graduação em Análise e Modelagem de Sistemas Ambientais da UFMG, Brasil tularuchkys@yahoo.com.br

Luiz Eduardo Panisset Travassos Doutor em Geografia pela PUC Minas e Doutor em Carstologia pela Universidade de Nova Gorica, Eslovênia Professor do Programa de pós-Graduação em Geografia da PUC Minas, Brasil $\underline{\text { luizpanisst@gmail.com }}$

Fernanda Mara Coelho Pizani Mestranda em Análise e Modelagem de Sistemas Ambientais pela UFMG, Brasil Bolsista da Fundação de Amparo à Pesquisa de Minas Gerais fm.coelho@yahoo.com.br

\begin{abstract}
Resumo
Diversos autores propuseram metodologias para aprofundar e sistematizar o conhecimento sobre a geodiversidade. Assim sendo, este artigo aborda o patrimônio espeleológico e suas relações espaciais com aspectos de seu ambiente físico com foco no Parque Nacional da Serra do Gandarela, Minas Gerais. As cavernas foram organizadas em grupos, dependendo da proximidade entre elas, criando áreas que facilitassem a análise espacial. O estudo permitiu uma melhor percepção dessa distribuição do patrimônio e suas relações espaciais com o ambiente físico, mostrando sua riqueza em termos da geodiversidade associada.
\end{abstract}

Palavras-chave: Patrimônio Espeleológico, cavernas, geodiversidade, ambiente físico, geoprocessamento 


\begin{abstract}
Several authors have proposed methodologies to deepen and systematize the knowledge of geodiversity. This paper approaches the speleological heritage and its spatial relationships with aspects of its physical environment, working on of the Serra do Gandarela National Park, Minas Gerais. The caves were organized into groups, depending on the proximity between them, creating areas that facilitated the spatial analysis. The study allowed better insight of this heritage distribution and its spatial relationships with the physical environment, showing its wealth in terms of the associated geodiversity.
\end{abstract}

Keywords: Speleological heritage, caves, geodiversity, physical environment, geoprocessing

\title{
1. INTRODUÇÃO
}

O Parque Nacional da Serra do Gandarela (PNSG), localizado em Minas Gerais, foi criado em outubro de 2014, com uma área de 31.270 hectares. Os objetivos de sua criação são: "garantir a preservação de amostras do patrimônio biológico, geológico, espeleológico e hidrológico associado às formações de canga do Quadrilátero Ferrífero, incluindo os campos rupestres e os remanescentes de floresta semidecidual, as áreas de recarga de aquíferos e o conjunto cênico constituído por serras, platôs, vegetação natural, rios e cachoeiras" (BRASIL, 2014). Assim, o patrimônio espeleológico associado à geossistemas ferruginosos presente na área do parque deve ter garantida sua proteção.

A criação desta unidade de conservação foi precedida de intenso debate com a sociedade, especialmente com segmentos ligados aos movimentos ambientais; instituições de ensino e pesquisa; moradores da área e entorno; além de representantes do setor produtivo, com destaque para o setor minerário; e do poder público. Entretanto, seu decreto de criação homologou área distinta daquela discutida em audiências públicas, o que tem gerado críticas dos diversos ramos em relação à efetiva proteção de seu patrimônio ambiental. Ficaram fora dos limites da unidade de conservação criada importantes nascentes e mananciais de água da Bacia do Ribeirão da Prata, considerados estratégicos para o abastecimento hídrico das cidades da Região Metropolitana de Belo Horizonte. Também não está contemplado pela demarcação do Parque um raro registro do patrimônio paleontológico e espeleológico: uma paleotoca cuja construção é atribuída a Mylodontidae cavadores (preguiças-gigantes de dois dedos), e que deveria ter garantida sua integridade num processo de geoconservação, conforme destacado por Ruchkys, Bittencourt, Carvalho e Buchmann (2014).

O Parque Nacional da Serra do Gandarela é caracterizado por uma rica biodiversidade e geodiversidade associadas ao geossistema ferruginoso - ameaçado por sua coincidência com áreas de interesse para mineração de ferro. Em termos nacionais, a proteção legal desse geossistema é pouco representativa o que tem levado a destruição de seu patrimônio associado, incluindo a supressão de cavidades naturais subterrâneas. Nesse contexto, o trabalho tem como objetivo 
contextualizar o patrimônio espeleológico do Parque Nacional da Serra do Gandarela considerando sua relação com alguns elementos do meio físico, a saber: litologia, pedologia e relevo - utilizando técnicas de geoprocessamento. Deste modo, busca melhorar o conhecimento e sistematização de sua ocorrência podendo auxiliar na elaboração do Plano de Manejo da unidade de conservação, instrumento obrigatório para seu uso científico, turístico e cultural.

\section{GEODIVERSIDADE E PATRIMÔNIO ESPELEOLÓGICO}

O termo geodiversidade foi utilizado pela primeira vez na Conferência de Malvern sobre a “Conservação Geológica e Paisagística”, ocorrida no Reino Unido em 1993 (PFALTZGRAFF; CARVALHO; RAMOS, 2010). Para Gray (2004), sua concepção veio da necessidade de abranger de forma integrada os elementos abióticos do meio natural. Serrano e Ruiz-Flaño (2007) salientam que várias definições foram propostas a partir de seu primeiro uso, incluindo algumas mais associadas à diversidade geológica e outras adotando uma visão mais holística abarcando outros elementos do meio físico.

Quando uma parcela especifica da geodiversidade apresenta valores (científico, didático, cultural, estético ou outros) caracteriza o patrimônio geológico que pode ser classificado em diferentes tipologias: geomorfológico, mineralógico, petrológico, hidrológico, pedológico, dentre outros. O patrimônio espeleológico, embora integre as tipologias de patrimônio geológico e geomorfológico também está associado a outros valores bióticos e culturais e é definido pelo Decreto Federal n $\mathrm{n}^{\mathrm{o}}$ 99.556/1990 (BRASIL, 1990), como “o conjunto dos elementos bióticos e abióticos, socioeconômicos e histórico-culturais, subterrâneos ou superficiais, representados pelas cavidades naturais ou a estes associados".

Tratar elementos da geodiversidade que tenham valores patrimoniais é uma questão bastante complexa, pois envolve aspectos legais que devem garantir sua proteção. No caso do patrimônio espeleológico, a Legislação Brasileira permite seu tratamento como parte do patrimônio cultural sendo considerado bem da União (BRASIL, 1988).

Para além dos avanços no campo teórico-conceitual envolvendo geodiversidade e patrimônio geológico alguns pesquisadores têm investido no desenvolvimento de métodos para sistematização e caracterização da geodiversidade. Alguns desses métodos se baseiam em outras áreas do conhecimento como é o caso da quantificação que considera os conceitos de riqueza e abundância aplicados nos estudos de biodiversidade. Pereira (2013) quantificou a geodiversidade da APA Sul, na qual o PNSG está parcialmente inserido, fazendo uma análise geoambiental para sítios selecionados em seu estudo, adaptando métodos por meios da aplicação destes conceitos. O uso de 
ferramentas de geoprocessamento tem se difundido em estudos que envolvem análises da biodiversidade, da geodiversidade e de patrimônios a elas associados.

Os avanços conceituais e metodológicos têm permitido um maior conhecimento da geodiversidade brasileira e do patrimônio a ela associado. No caso específico do patrimônio espeleológico ainda há muito por fazer. Piló e Auler (2010) estimaram o potencial de ocorrência de cavernas no Brasil acima de 310.000 cavidades. Em dezembro de 2017, a base oficial de dados de ocorrência de cavidades, mantida pelo Centro Nacional de Pesquisa e Conservação de Cavernas CECAV registrava a ocorrência de 17.488 cavernas, o que representa pouco mais de $5 \%$ do potencial estimado pelos autores.

\section{3. ÁREA DE ESTUDO}

O PNSG está situado a cerca de $50 \mathrm{~km}$ de Belo Horizonte, sendo o principal acesso realizado pela rodovia MG-030, através do município de Rio Acima (Figura 1). Diversos elementos importantes da geodiversidade são conhecidos no parque, onde destacamos a ocorrência de 265 cavidades naturais subterrâneas desenvolvidas em rochas ferruginosas, carbonáticas e siliciclásticas.

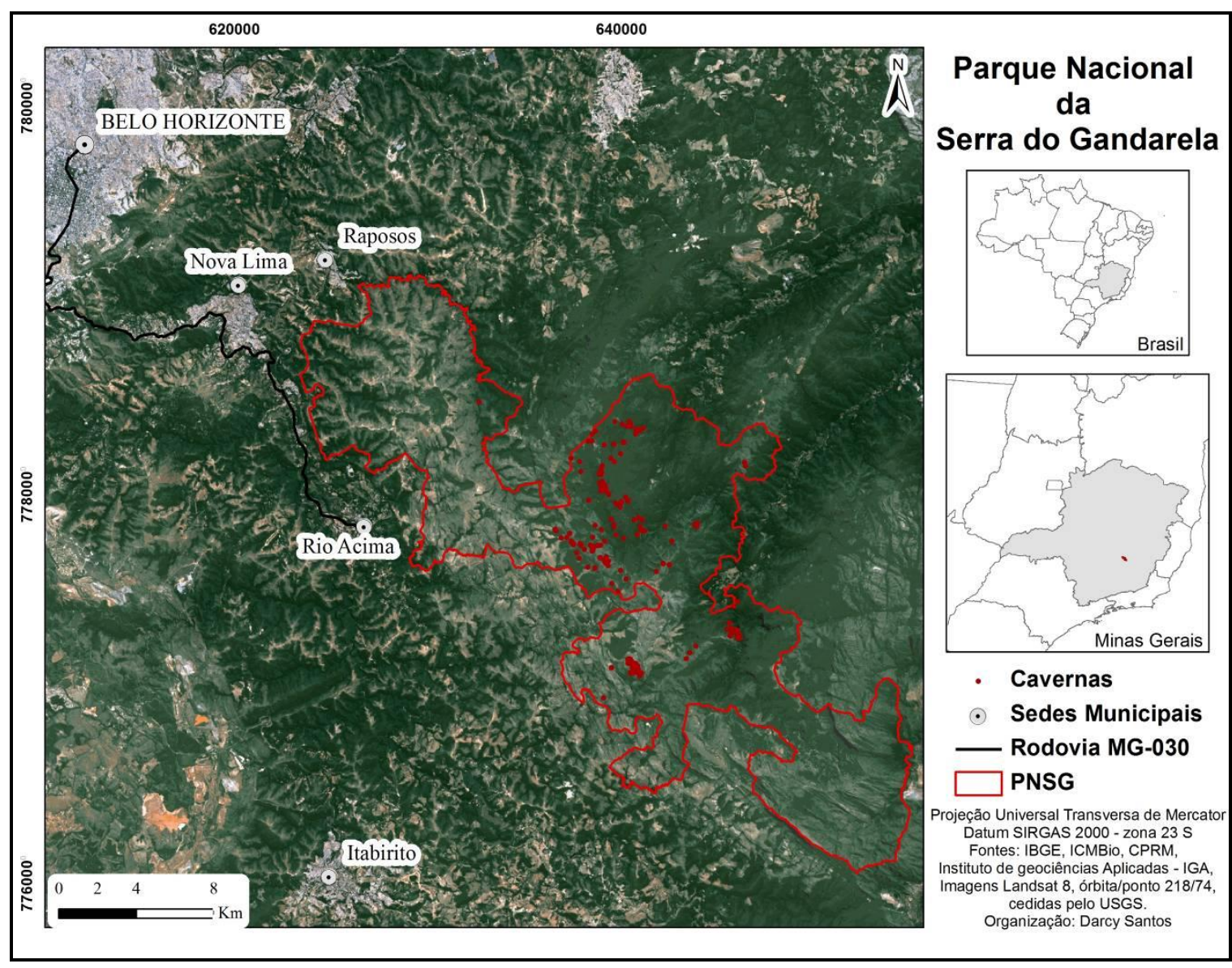

Figura 1 - Localização do Parque Nacional da Serra do Gandarela. Os pontos vermelhos indicam a localização das cavernas. 
O Parque Nacional está no divisor hidrográfico entre as bacias dos rios São Francisco e Doce e sua importância hídrica foi uma das causas para sua criação. Diversos corpos d'água têm suas nascentes, total ou parcialmente, dentro de seus limites. Os cursos d'água de sua face oeste, como o Ribeirão da Prata e os córregos do Viana e do Mingu, drenam para a Bacia do Rio das Velhas, afluente do São Francisco. Os da face leste, como os rios Conceição e Barão de Cocais e o Ribeirão Preto drenam para a bacia do Piracicaba, afluente do Rio Doce. Parte destes corpos está associada ao sistema aquífero Itabirítico, considerado o principal sistema aquífero da APA Sul da Região Metropolitana de Belo Horizonte (BEATO; MONSORES; BERTACHINNI, 2005).

$\mathrm{Na}$ área ocorrem duas unidades litoestratigráficas principais. O Supergrupo Rio das Velhas, constituído por rochas metavulcânicas e metassedimentares, de idade arqueana, encontra-se exposto nas porções noroeste e centro sul da área, representado pelos grupos Nova Lima e Maquiné. O Supergrupo Minas, do Paleoproterozóico, está presente na parte central da área, representado pelos Grupos Caraça, Itabira, Piracicaba e Sabará. Ocorre ainda, em menor escala, depósito lacustrino, de idade cenozóica, na bacia do Gandarela, coberturas detrito-lateríticas e depósitos aluviais, constituídos por rochas fanerozóicas.

Apresenta altitudes predominantemente entre 1.000 e 1.300 metros, com as mínimas, por volta de 750 metros, próximo à calha do Rio das Velhas, nos municípios de Raposos e Nova Lima. Em regiões cimeiras, especialmente associadas às coberturas de canga do Sinclinal Gandarela, as altitudes ultrapassam os 1.500 metros. Algumas regiões ao sul da área, associados principalmente ao litotipo Quartizito, conglomerado e filito, da Formação Moeda, ultrapassam os 1.700 metros.

Os tipos litológicos associados a fatores estruturais e bioclimáticos condicionaram, em sua origem e evolução, os compartimentos morfoestruturais identificadas no Quadrilátero Ferrífero (MEDINA; DANTAS; SAADI 2005). Na área de estudo, ocorrem cinco destas unidades de morfoestrutura: o compartimento Vale Anticlinal do Rio das Velhas (onde o relevo é constituído principalmente por morros de topos ou cristas aguçadas), o compartimento Patamares Escalonados da Serra do Jaguará (que apresenta relevo marcado por serras/patamares, colinas e platôs quartzíticos), o compartimento Crista Sinclinal da Serra do Ouro Fino (onde as serras, platôs quartziticos, platôs lateríticos e escarpas são as formas predominantes de relevo), o compartimento Depressão Suspensa do Sinclinal Gandarela (onde se encontra o relevo mais movimentado da área de estudo, com predomínio de morros de topos ou cristas aguçados, escarpas e colinas), o compartimento Vale Anticlinal do Rio Conceição (que apresenta relevo dominado pelos esporões, morros alongados de topos arredondados e também por colinas) e o compartimento Maciço do Caraça (onde os morros de topos arredondados são as principais formas de relevo, ocorrendo também, em menor escala, escarpas, colinas, montanhas e planícies aluviais). 
$\mathrm{Na}$ área, foram identificadas as classes de solos Argissolo Vermelho-Amarelo, Cambissolo Háplico, Gleissolo Háplico, Latossolo Vermelho, Latossolo Vermelho-Amarelo, Neossolo Flúvico e Neossolo Litólico. Em algumas áreas a cobertura de solo está ausente e apresentam exposições de canga, afloramentos de rocha e também áreas degradadas. Embora tenham sido identificadas estas classes de solo, destaca-se que os cambissolos e neossolos, solos pouco evoluídos, prevalecem na área, além dos afloramentos de rocha. Shinzato e Carvalho Filho (2005) salientam que estes solos são muito influenciados pelos materiais de origem, apresentam grande concentração de minerais, são pouco profundos e com baixa resistência ao intemperismo. Estão associados a relevos movimentados o que, em períodos úmidos, facilita o transporte de material sólido, favorecendo processos modificadores do relevo.

\section{MATERIAIS E MÉTODOS}

Foram organizadas as bases de dados disponíveis referentes à área de estudo. Utilizou-se os mapas de geologia, geomorfologia, pedologia, hidrogeologia e relevo, do projeto APA Sul RMBH (CPRM, 2005), na escala de 1:50.000, elaborados pelo Serviço Geológico do Brasil - CPRM, Secretaria Estadual de Meio Ambiente e Desenvolvimento Sustentável - SEMAD e Companhia Energética de Minas Gerais CEMIG. O arquivo digital com os limites do Parque Nacional foi obtido junto ao Instituto Chico Mendes de Conservação da Biodiversidade - ICMBio. A base de dados de ocorrência de cavernas foi obtida junto ao Centro Nacional de Pesquisa e Conservação de Cavernas - CECAV, vinculado ao ICMBio (CECAV, 2015). Utilizou-se também imagem ASTER GDEM (Advanced Spaceborne Thermal Emission and Reflection Radiometer - Global Digital Elevation Model), com resolução de 30 metros, para processamento dos dados de elevação. $\mathrm{O}$ Google Earth foi utilizado como apoio na identificação do porte da vegetação existente na área.

O trabalho foi realizado em ambiente SIG, por meio de processos cartográficos e espaciais, utilizando o software ArcGis (versão 9.3). Inicialmente, foi realizada a padronização das bases, sendo adotado o Sistema de Projeção Universal Transversa de Mercator, Datum SIRGAS 2000, zona $23 \mathrm{~S}$, conforme apresentado na figura 2.

Adaptando os métodos propostos por Manosso e Ondicol (2012) e por Schmitz e Novasco (2011), abordou-se o patrimônio espeleológico e suas relações com aspectos do meio físico onde se insere. Para a realização das análises espaciais, foi utilizada a função de áreas de proximidade (buffer) que cria polígonos no entorno de elementos a partir de uma distância definida pelo usuário. Foi utilizada a distância de 250 metros, medida a partir do ponto de entrada das cavidades. Os polígonos que apresentaram áreas de interseção entre si, ou seja, possuíam cavernas a menos de 250 
metros de distância, foram unidos, gerando polígonos maiores. Deste modo, foram gerados 33 polígonos, agrupando as 265 cavidades.

Embora o objetivo do trabalho não fosse realizar estudos referentes à área de influência das cavidades, optou-se por utilizar o entorno de 250 metros, para definição dos agrupamentos entre estas. Este valor é apontado pela legislação ambiental como área inicial de análise, enquanto não são definidos os limites adequados para a área de influência das cavernas (CONAMA, 2004).

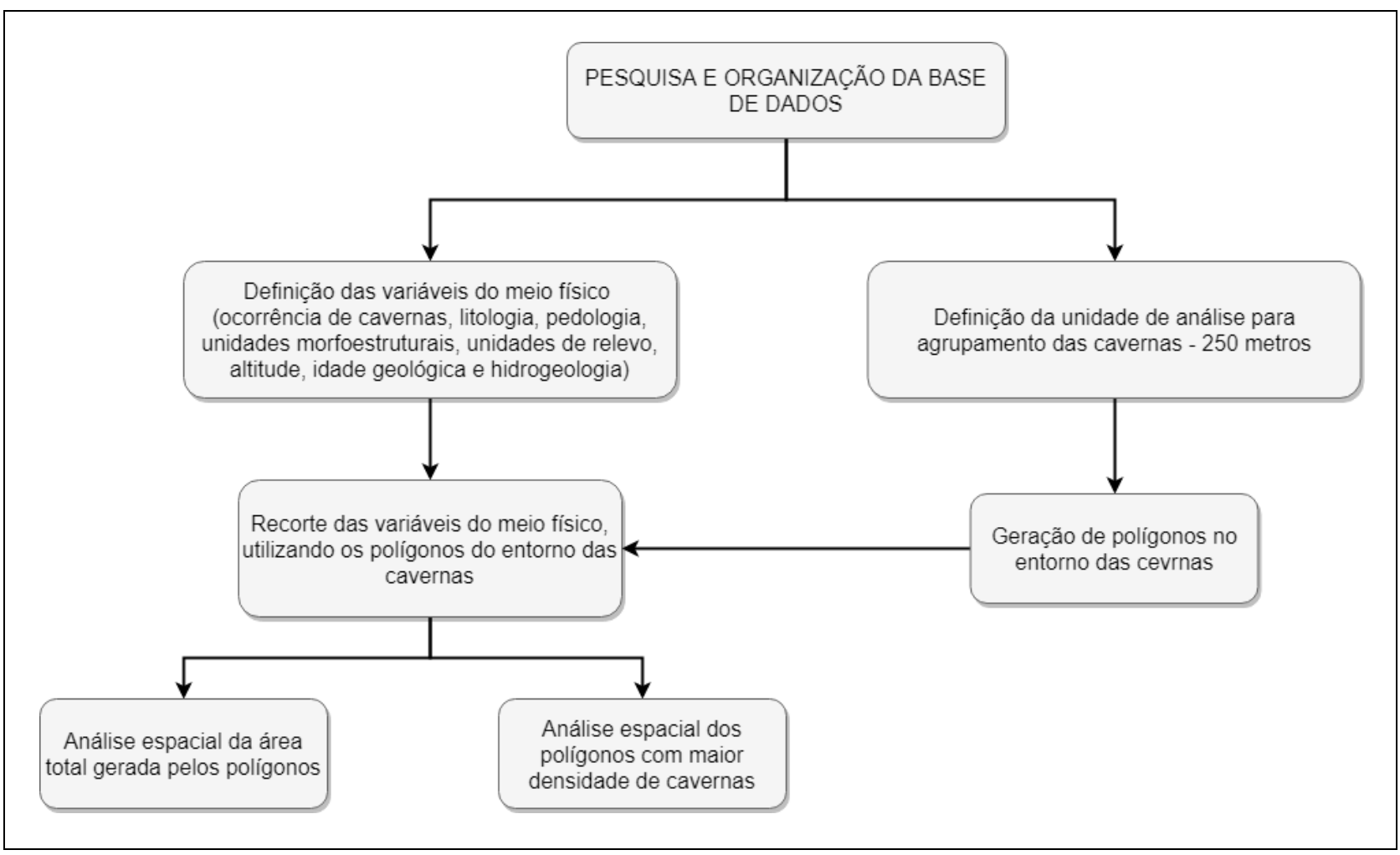

Figura 2 - Fluxograma da metodologia utilizada no trabalho

Em seguida, as variáveis físicas foram recortadas utilizando os 33 polígonos. Foram calculadas as áreas ocupadas por todos os elementos de cada uma das variáveis físicas nestes polígonos. Os recortes produzidos foram utilizados para análises espaciais referentes ao contexto da geodiversidade onde estão inseridas as cavidades naturais. Foram analisadas as variáveis físicas, considerando a área total gerada pelos 33 polígonos, assim como os polígonos que apresentaram maior densidade de cavernas.

\section{Resultados}

Os 33 polígonos apresentaram áreas variando entre 16 e 246 hectares, contendo entre uma e 56 cavidades. A área total coberta por eles foi de 1.653 hectares, o que corresponde a 5,3\% parque nacional, indicando forte concentração das cavidades naturais em algumas regiões. 
Quanto à litologia, observa-se que os polígonos gerados interceptam 18 dos 29 litotipos descritos na região de estudo. A maior parte da área ocupada por estes $(67,71 \%)$ coincide com três litotipos: dolomito, itabirito dolomítico, filito dolomítico e argiloso (36,89\%), itabirito, itabirito dolomítico e corpos de hematita (15,53\%) e fragmentos de itabirito e hematita compacta, cimentados por limonita (15,29\%), evidenciando forte correlação entre os litotipos associados às rochas ferruginosas e as cavernas na área de estudo (Figura 3).

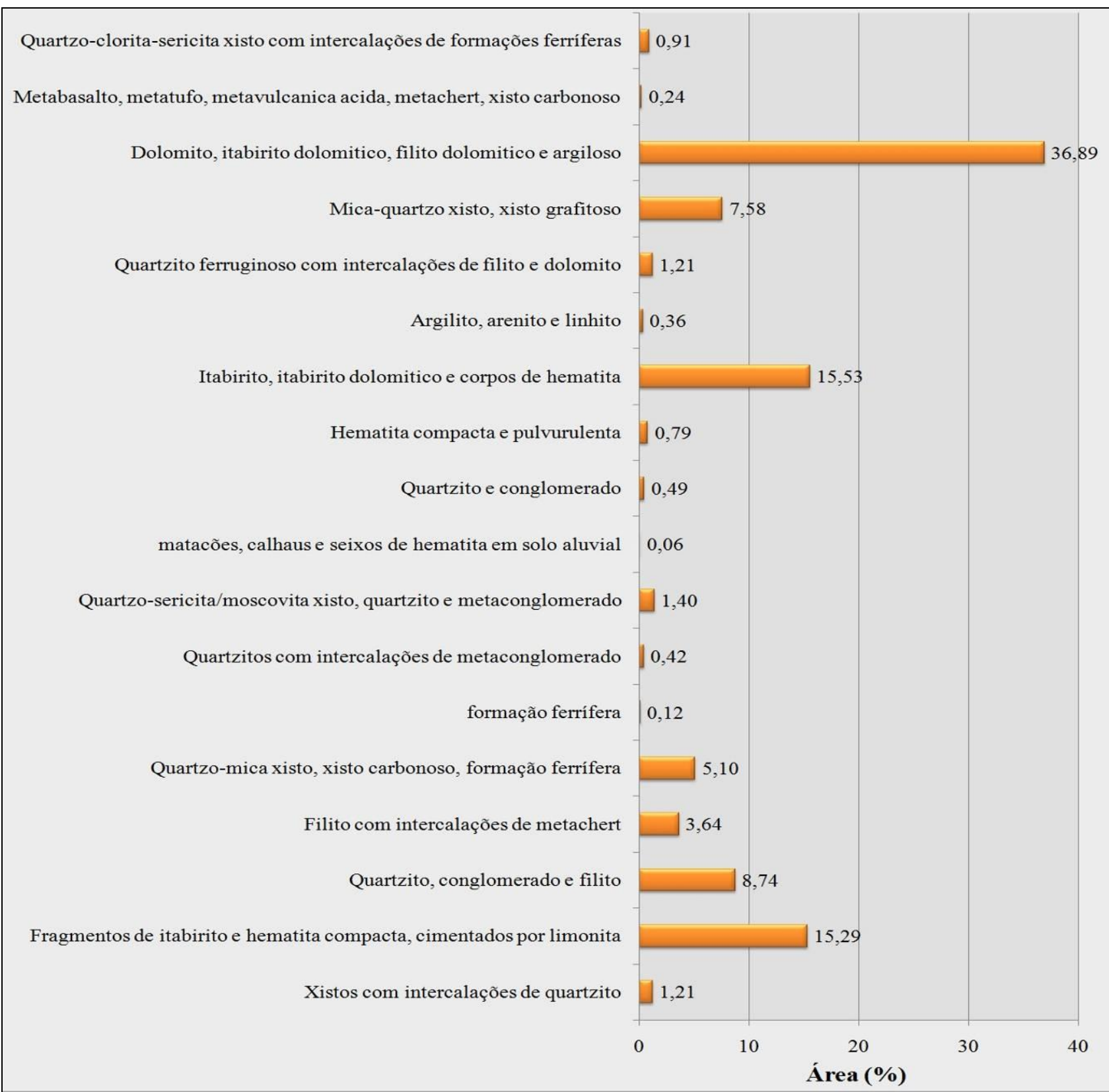

Figura 3 - Litotipos associados ao Patrimônio Espeleológico (entorno de 250 metros). Percentual de área ocupado nos polígonos.

Em relação às unidades morfoestruturais, observa-se que 69,24\% das áreas dos polígonos coincidem com a Depressão Suspensa do Sinclinal Gandarela (Figura 4). Por outro lado, os polígonos não interceptaram áreas no Maciço da Caraça e no Vale Anticlinal do Rio das Velhas. 
Este fator pode estar relacionado ao maior esforço de prospecção espeleológica naquela unidade morfoestrutural, já que concentra a ocorrência de rochas ferruginosas de interesse para as pesquisas minerárias.

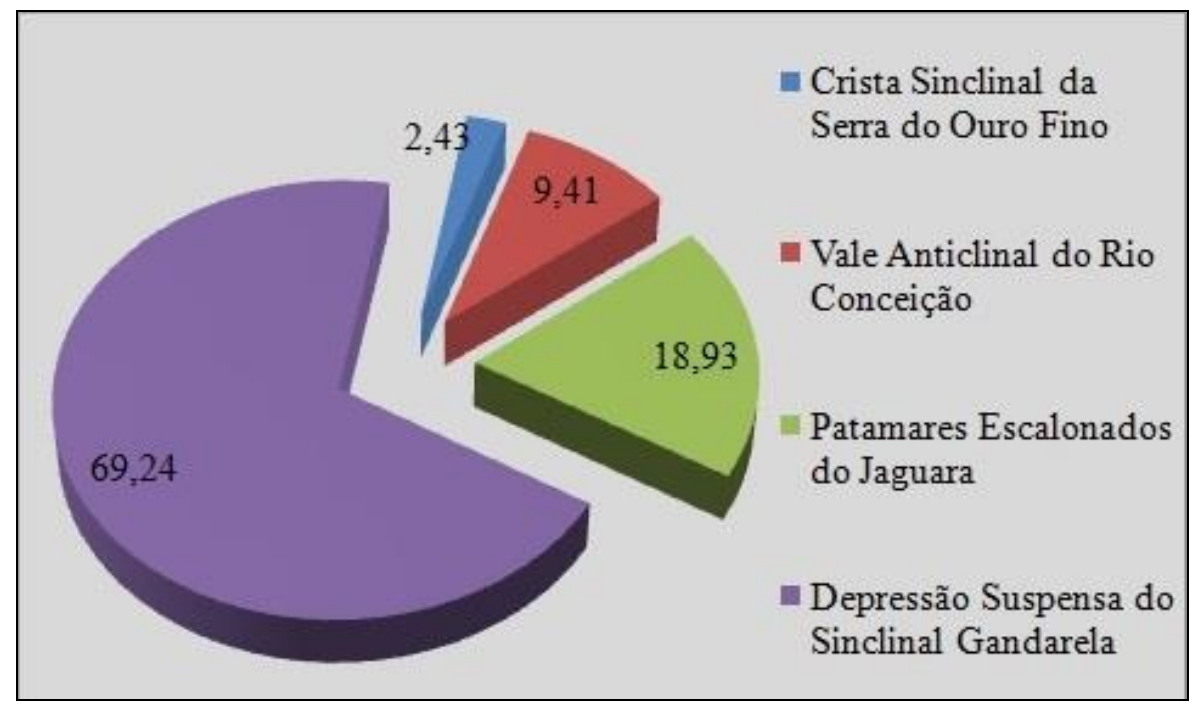

Figura 4 - Unidades morfoestruturais associadas ao Patrimônio Espeleológico (entorno de 250 metros). Percentual de área ocupado nos polígonos.

São identificadas quatorze unidades de relevo na área de estudo. Os polígonos gerados no entorno das cavidades não interceptaram quatro destas unidades (morros de topos arredondados, montanhas, platôs quartzíticos e rampas de colúvio). Cerca de $60 \%$ da área dos polígonos estão situados nas unidades de relevo Escarpas (31,05\%) e Morros de topos ou cristas aguçadas $(29,18 \%)$, conforme se pode observar pela figura 5. Parte desta questão é explicada por um dos processos genéticos de formação das cavidades relacionadas às rochas ferruginosas. A existência de relevo escarpado associado a locais onde ocorre a quebra da canga possibilita o aumento do potencial hidráulico favorável aos processos erosivos atuantes na formação destas cavidades.

As coberturas de canga ocupam pouco mais de $12 \%$ da área dos polígonos, enquanto afloramentos de rocha ocupam cerca de $10 \%$. Pequena parcela da área dos polígonos $(0,12 \%)$ é constituída por áreas degradadas. Importante ressaltar que a prevalência de solos pouco desenvolvidos associados ao relevo movimentado condiciona a vulnerabilidade ambiental da região, favorecendo processos erosivos, modificadores do relevo. Estes processos são atenuados pela cobertura vegetal que auxilia na estabilidade dos solos. 


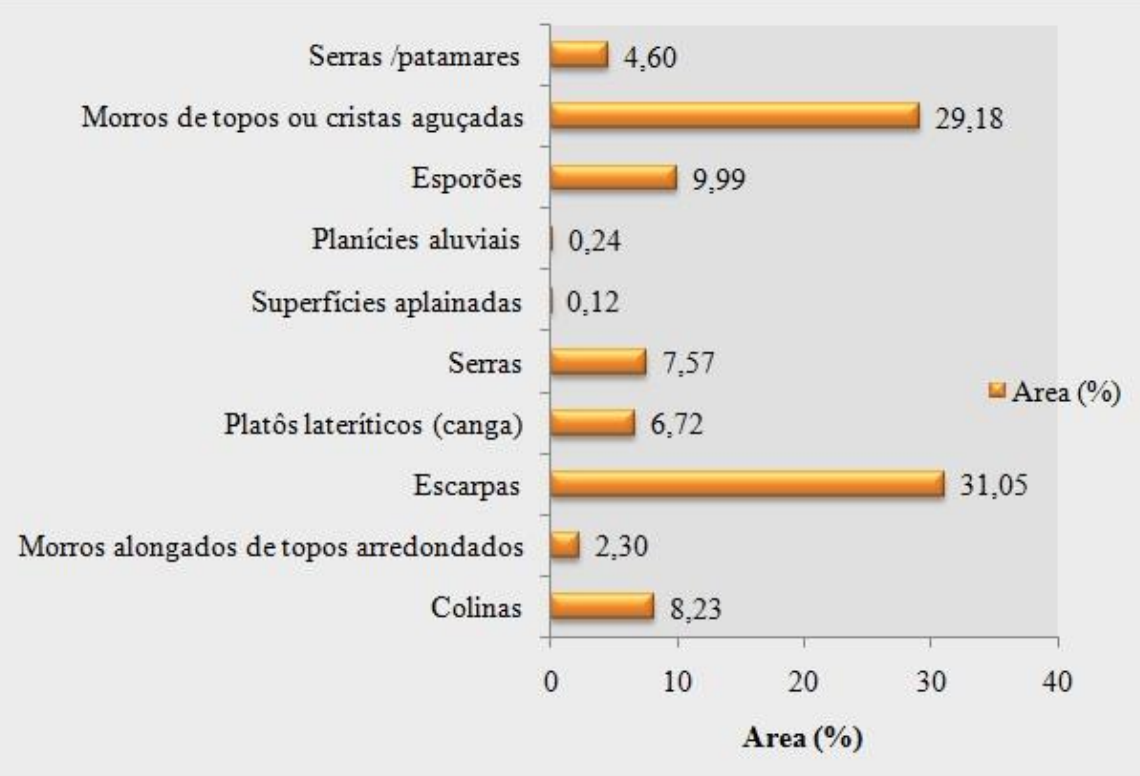

Figura 5 - Unidades de relevo associadas ao Patrimônio Espeleológico (entorno 250 metros). Percentual de área ocupado nos polígonos.

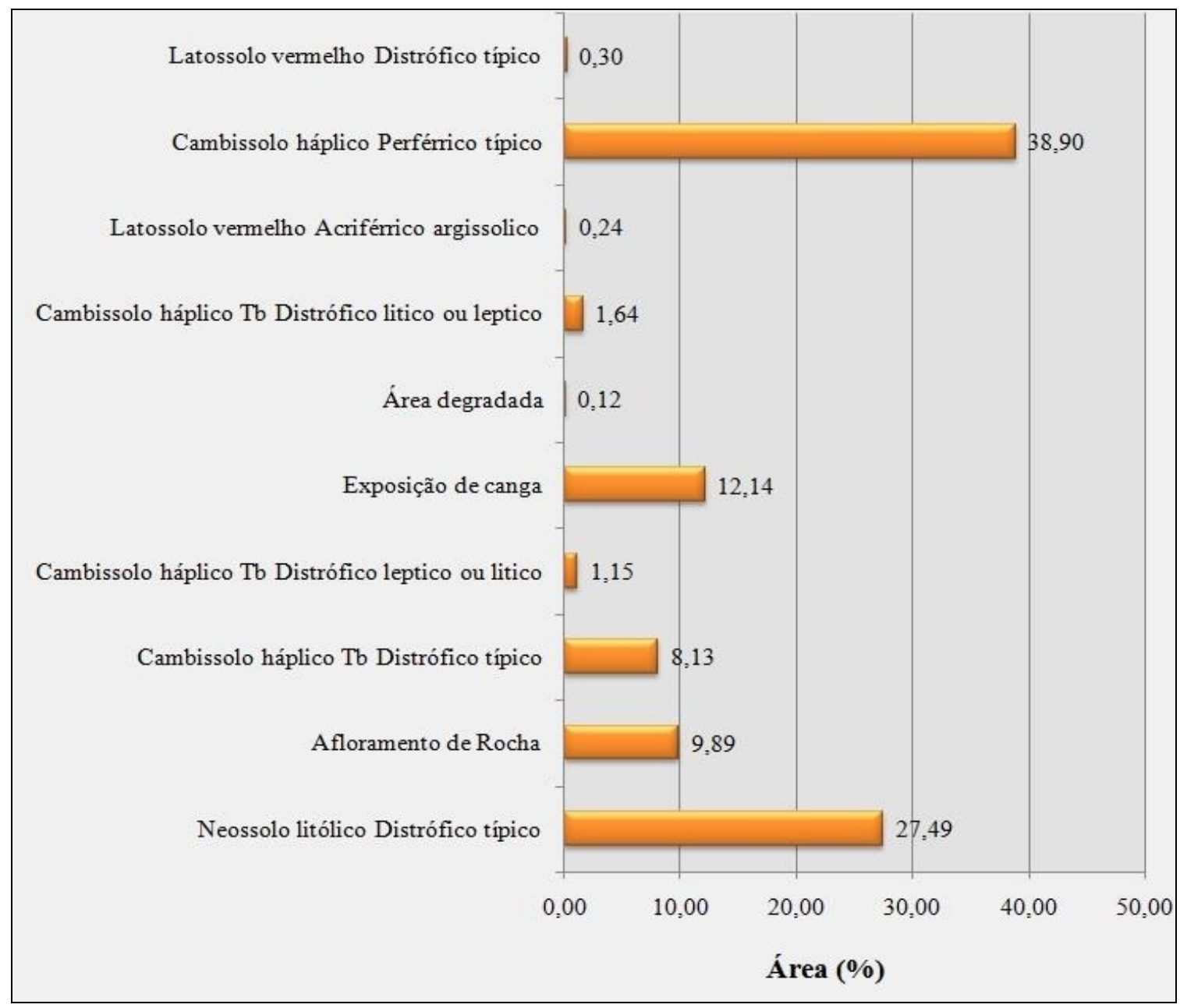

Figura 6 - Solos associados ao Patrimônio Espeleológico (entorno de 250 metros) 
Rochas de idade paleoproterozóica ocorrem em $66,81 \%$ da área dos polígonos, enquanto rochas do Mesoarqueano-Neoarqueano ocupam 17,48\% e do Cenozóico 15,72\% (Figura 7).

Analisando os polígonos gerados, fica mais evidente a forte concentração das cavernas em algumas regiões. Dos 33 polígonos, treze apresentaram apenas uma cavidade. Por outro lado, cinco polígonos concentraram 177 cavidades, o que corresponde a 66,8\% das cavernas conhecidas. Considerando a área total de estudo, observa-se que a densidade média é de 0,01 cavernas por hectare. Se tomarmos somente os polígonos onde estas foram localizadas, a densidade média sobe para 0,16 cavernas por hectare (Figura 8).

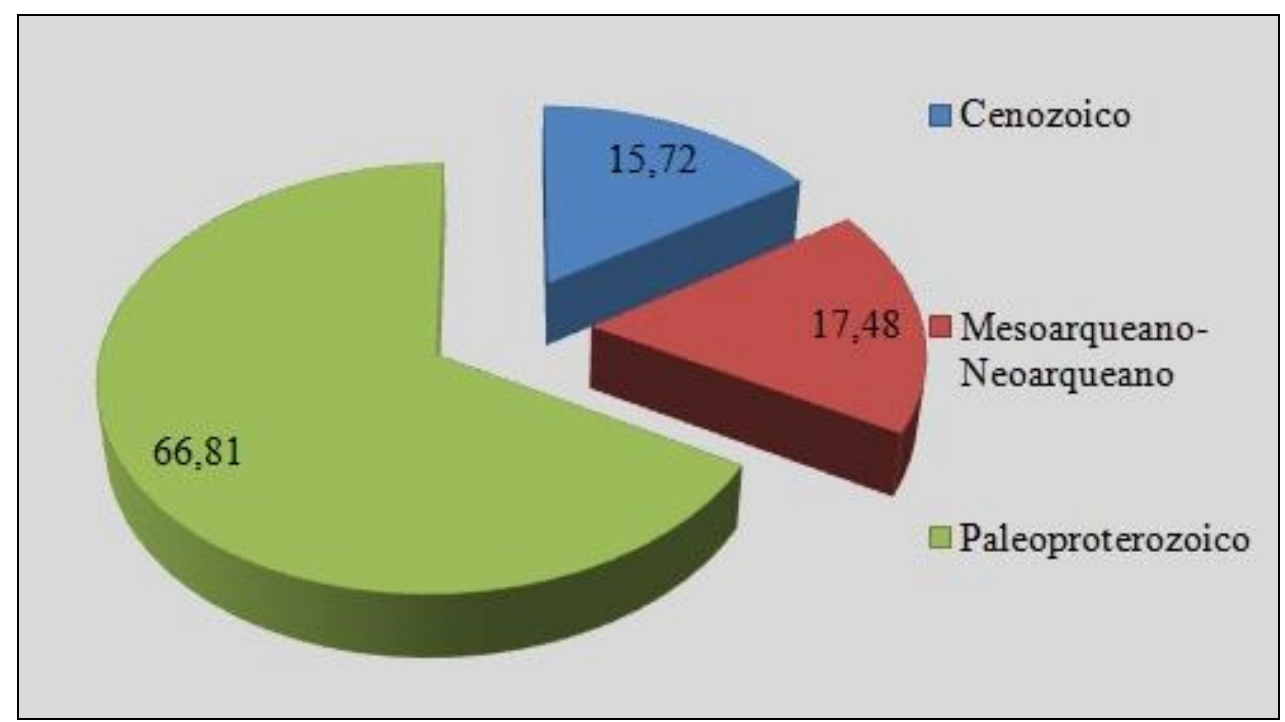

Figura 7- Idades geológicas das rochas associadas ao Patrimônio Espeleológico (entorno de 250 metros). Percentual de área ocupado nos polígonos.

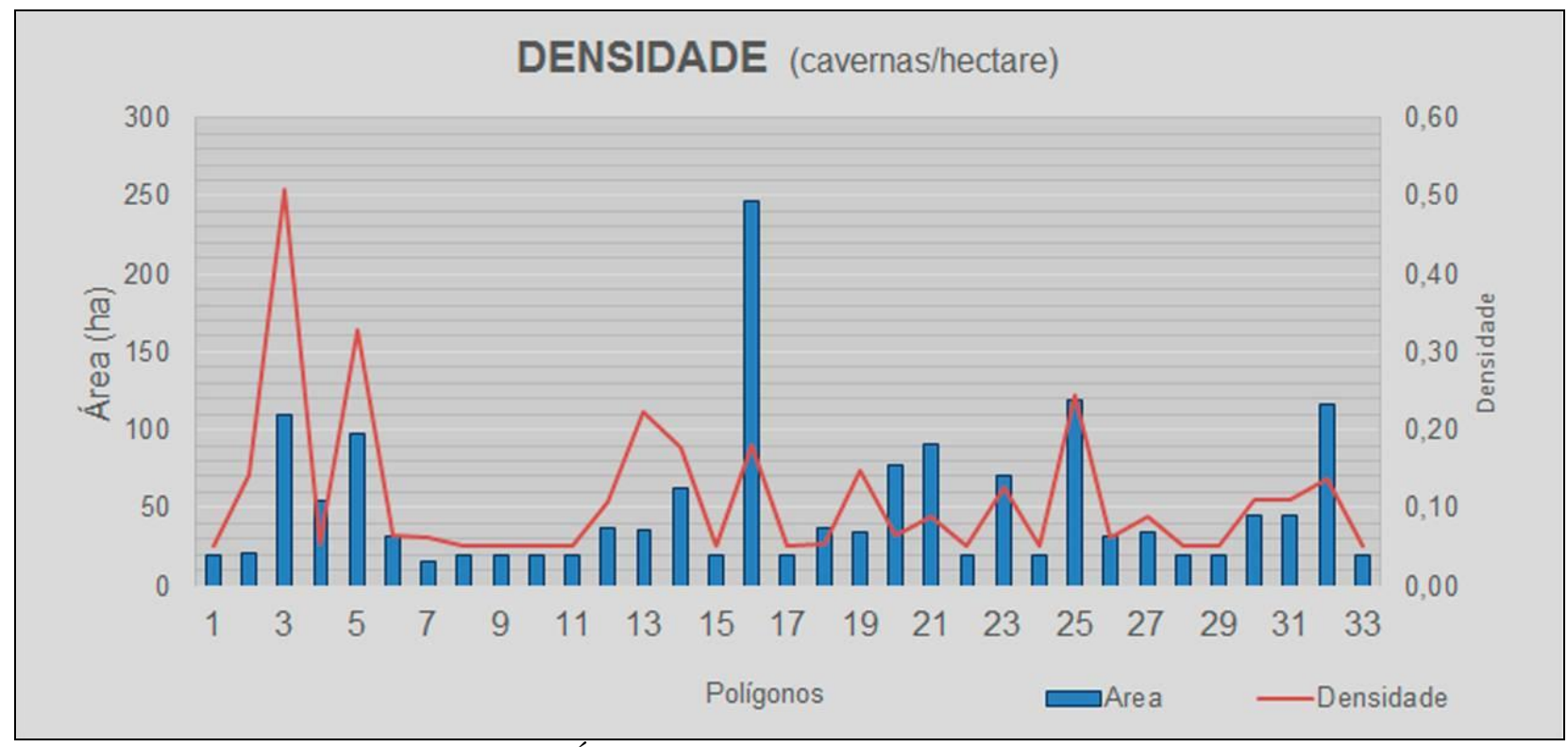

Figura 8- Área e densidade de cavernas nos polígonos 
Seis polígonos $(3,5,13,14,16$ e 25$)$ apresentaram densidade de cavernas acima da média ( 0,16 cavidades/hectare). Analisando cada um destes, é possível deduzir quais os elementos do meio físico estão associados à maior ocorrência de cavidades nos mesmos. Também é importante observar a grande variabilidade dos elementos da geodiversidade aos quais estão associadas às cavidades naturais subterrâneas na área de estudo, o que reforça a importância deste patrimônio no Parque Nacional da Serra do Gandarela.

O polígono 3 está situado na porção sudoeste da área de estudo, no município de Itabirito. Concentra 56 cavernas em 110 hectares, o que corresponde à maior densidade encontrada $(0,51$ cavernas/hectare). Suas variáveis geoambientais são apresentadas na Figura 9.

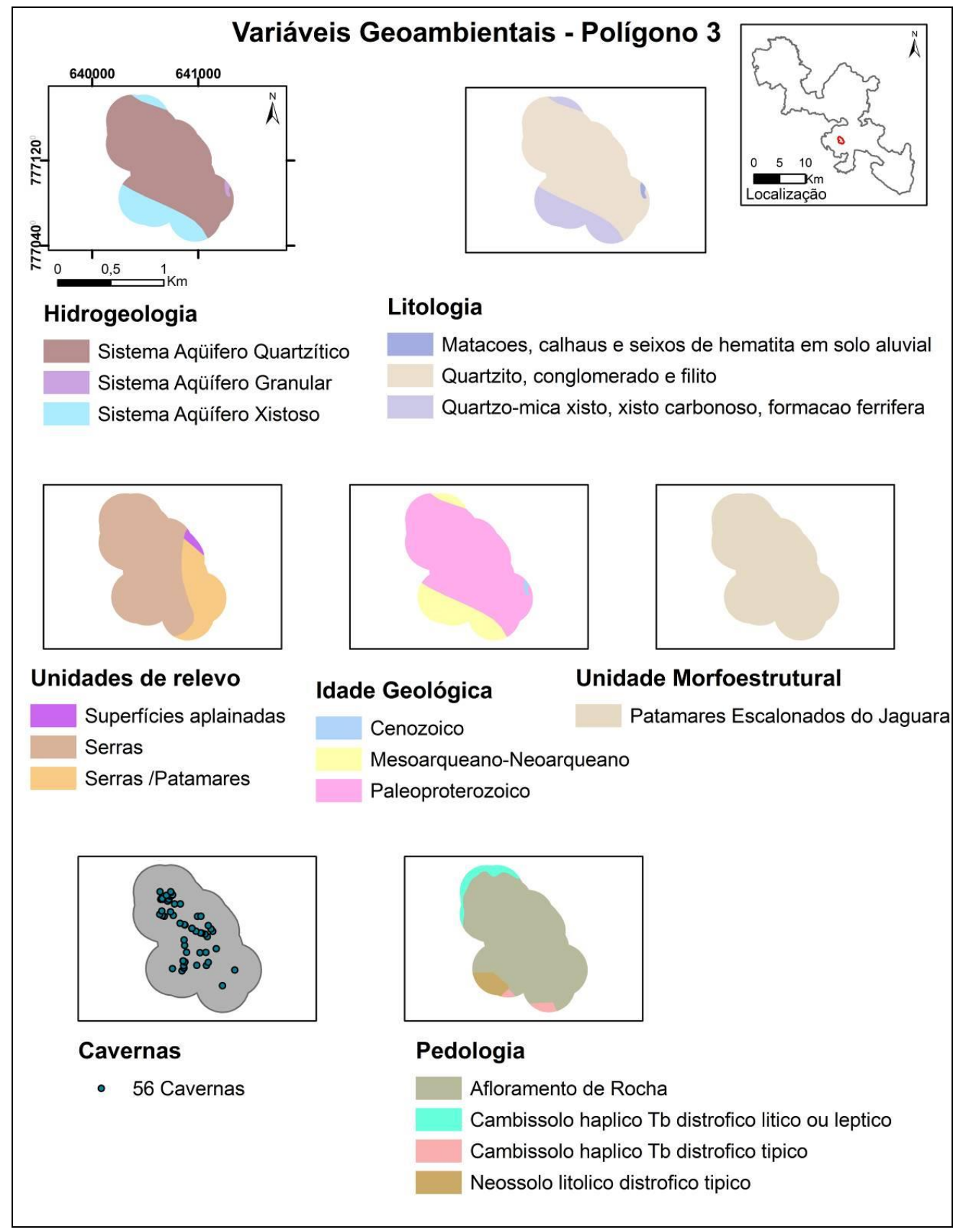

Figura 9- Variáveis geoambientais associadas ao Patrimônio Espeleológico no polígono 3. 
Este polígono está totalmente inserido na unidade morfoestrutural Patamares escalonados do Jaguara. Apresenta altitudes entre 1.200 e 1.500 metros. Predominam as rochas siliciclásticas, onde o litotipo quartzito, conglomerado e filito, de idade paleoproterozóica, ocupa $81 \%$ da área, associado a sistema aquífero granular. Quanto à pedologia, em $88 \%$ da área predominam afloramentos de rocha. Nos outros $12 \%$, ocorrem cambissolos e neossolos.

A cobertura vegetal é composta, sobretudo, por vegetação de porte herbáceo (Figura 10). Nas calhas de drenagem, esta vegetação assume porte arbustivo, com árvores isoladas. Muitas cavidades também estão associadas a estas drenagens.

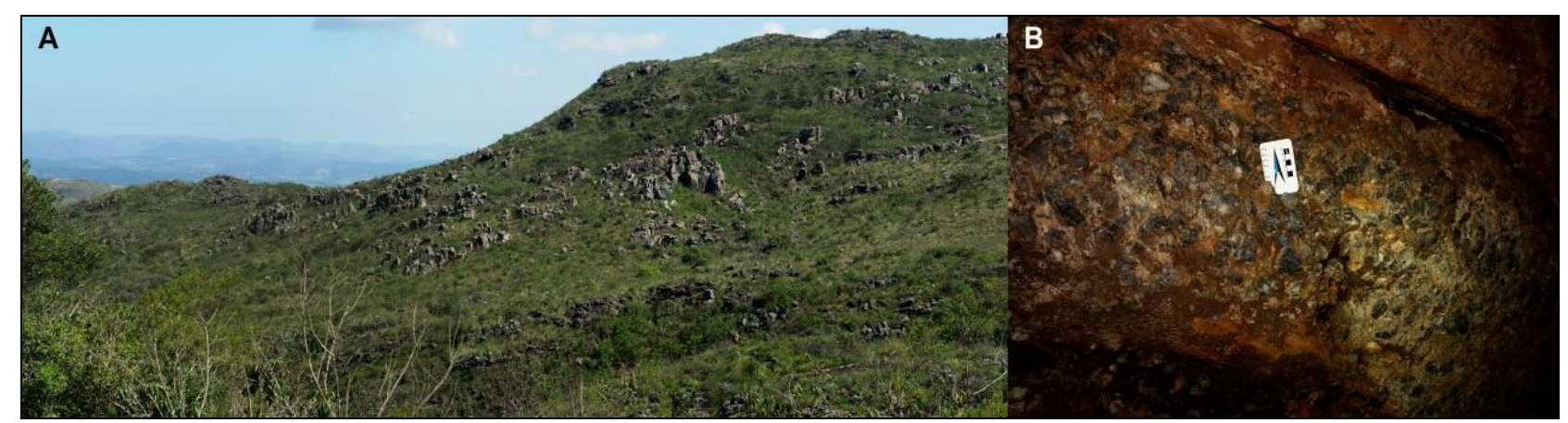

Figura 10 - Vista parcial do poligono3 (a), com vegetação herbácea e afloramentos rochosos. Em (b) detalhe interno da parede de uma das cavernas do polígono, onde se pode observar o conglomerado.

O polígono 5 está situado na porção sudeste da área de estudo, no município de Santa Bárbara, apresentando altitudes entre 900 e 1.200 metros. Possui 32 cavernas em 98 hectares e, portanto, densidade de 0,33 cavernas por hectare. Suas variáveis geoambientais são apresentadas na figura 11.

A maior parte de sua área (87\%) está inserida na unidade morfoestrutural Vale anticlinal do Rio Conceição. O tipo litológico mica-quartzo xisto, xisto grafitoso, do MesoarqueanoNeoarqueano, ocorre em $87 \%$ da área. A cobertura pedológica é composta por neossolos (80\%) e cambissolos (14\%), além de áreas em que a rocha está aflorante (6\%). A cobertura vegetal associada é composta por vegetação de porte arbóreo, exceto nas áreas onde a rocha está exposta.

O polígono 13 está localizado na porção centro-sul da área de estudo, no município de Santa Bárbara. Ocupa área de 36 hectares, contendo 8 cavernas, resultando em densidade de 0,22 cavernas por hectare. Suas variáveis geoambientais são apresentadas na figura 12.

A maior parte de sua área está inserida na unidade morfoestrutural Depressão Suspensa do Sinclinal Gandarela (69\%), com altitudes em torno de 1.300 a 1.400 metros. O litotipo fragmentos de itabirito e hematita compacta, cimentados por limonita, de idade cenozóica, ocupa 53\% da área, enquanto o itabirito, itabirito dolomítico e corpos de hematita, do paleoproterozóico ocupam 14\%. Além das rochas ferruginosas ocorrem os litotipos filito com intercalações de metachert (30\%) e quartzito, conglomerado e filito (3\%). O relevo é condicionado pela cobertura de canga que ocorre 
em $67 \%$ da área, em sua porção central. A oeste, a quebra da canga favorece a ocorrência de escarpas (3\%) e a leste ocorrem esporões (30\%). Em relação à pedologia, neossolos cobrem 33\% da área e cambissolos, $20 \%$. O restante da área (47\%) é caracterizado pela exposição da canga.

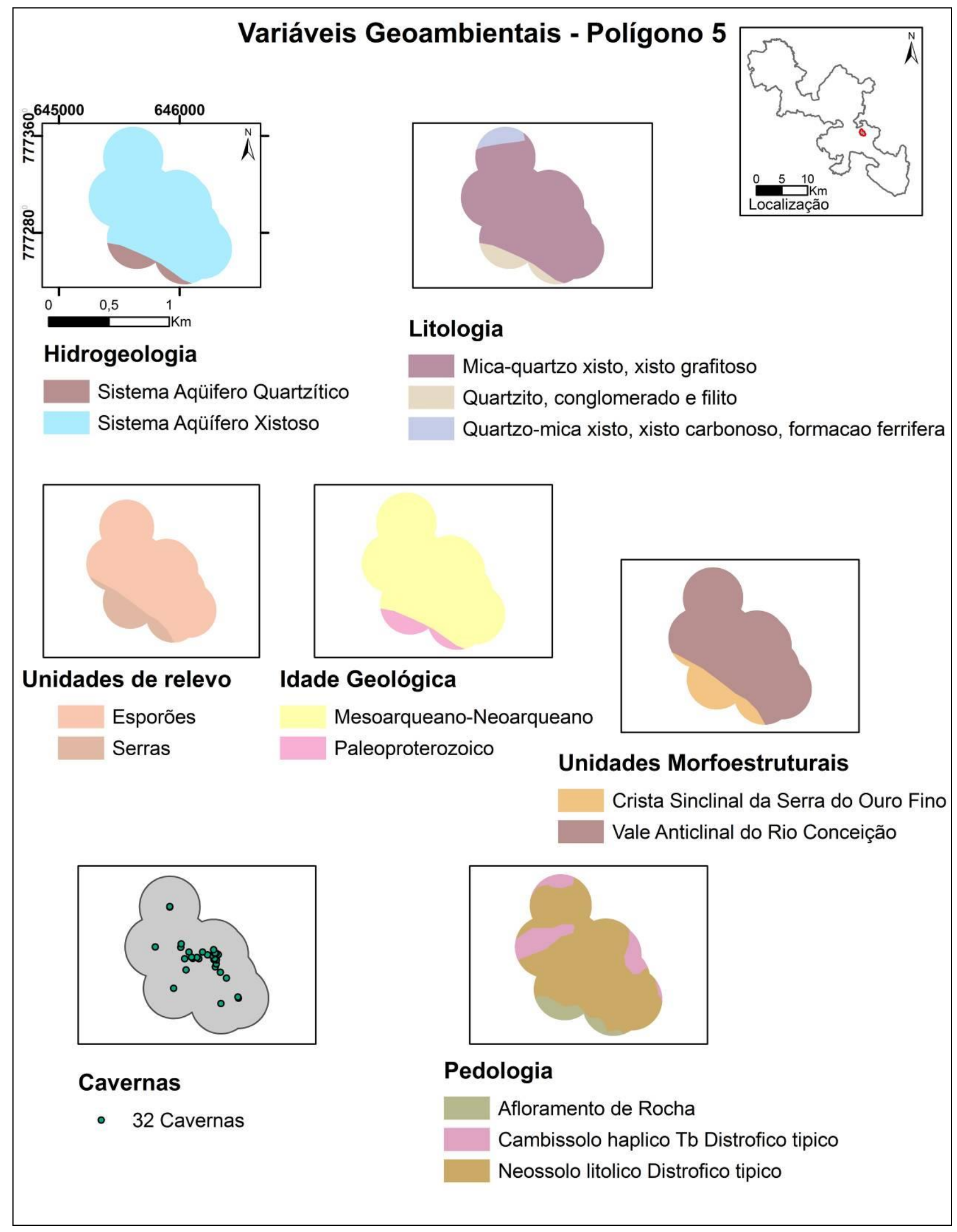

Figura 11- Variáveis geoambientais associadas ao Patrimônio Espeleológico no polígono 5 


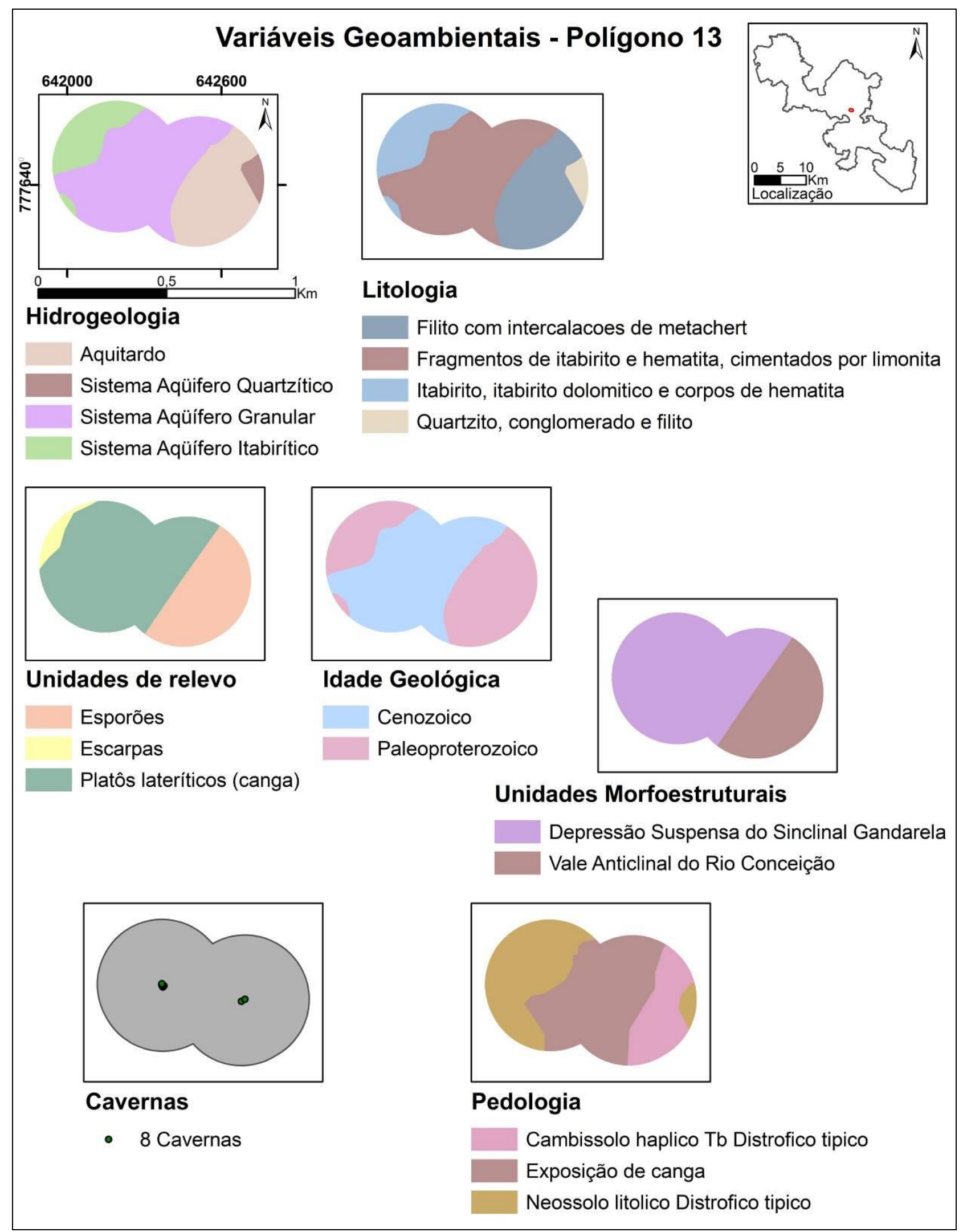

Figura 12- Variáveis geoambientais associadas ao Patrimônio Espeleológico no polígono 13 
Na parte central do polígono, vegetação herbácea, do tipo campo ferruginoso, associa-se a cobertura de canga (Figura 13). Em alguns pontos isolados, quebras na estrutura da canga permitiram a deposição de pequenas manchas de solo e, assim, a fixação de vegetação de porte arbustivo e arbóreo. Permitiu também a exposição de cavidades, as quais apresentam, de forma geral, desenvolvimento superficial e pequenas dimensões (Figura 13). Nas direções leste e oeste, predomina vegetação de porte arbóreo, associada aos neossolos e cambissolos.

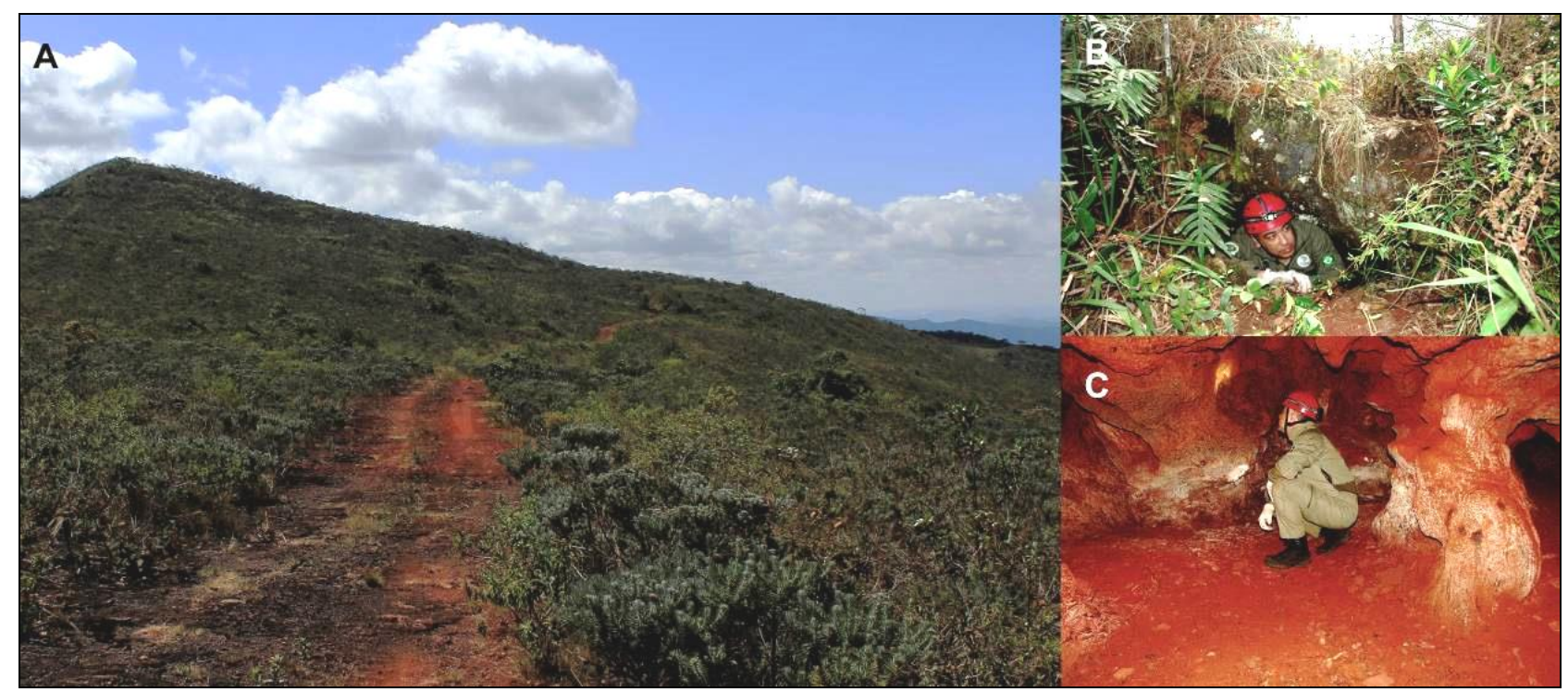

Figura 13 - Vista parcial do polígono 13, com vegetação herbácea sobre cobertura de canga (a). Detalhe da entrada de uma das cavernas no polígono (b) e interior de uma das cavernas do polígono (c)

O polígono 14 está situado, em sua maior parte, no município de Santa Bárbara e, uma pequena parte, no município de Rio Acima. Possui área de 62 hectares, onde ocorrem 11 cavernas ( 0,18 cavernas/hectare). A figura 14 apresenta suas variáveis geoambientais.

Este polígono está inserido na unidade morfoestrutural Depressão Suspensa do Sinclinal Gandarela, sendo constituído por rochas ferruginosas. Ocorrem os litotipos fragmentos de itabirito e hematita compacta cimentados por limonita, de idade cenozóica (73\%) e itabirito, itabirito dolomítico e corpos de hematita, de idade paleoproterozóica (27\%). Em relação à pedologia, neossolos litólicos cobrem $45 \%$ da área e a exposição de canga ocupa o restante (55\%).

As altitudes variam entre 1.260 metros, na face leste, e 1.520 na face oeste do polígono. Vegetação herbácea, do tipo campo ferruginoso, cobre a maior parte da área, especialmente nas maiores altitudes. As áreas de menor altitude estão associadas aos neossolos, que possibilitaram a fixação de vegetação de maior porte em alguns locais, especialmente quando próximos às calhas de drenagem.

O polígono 16 está localizado entre os municípios de Santa Bárbara e Rio Acima. Possui 246 hectares, constituindo-se na maior área dentre os polígonos analisados. Abrange 44 cavidades, 
o que representa densidade de 0,18 cavernas por hectare. Suas variáveis geoambientais são apresentadas na figura 15.

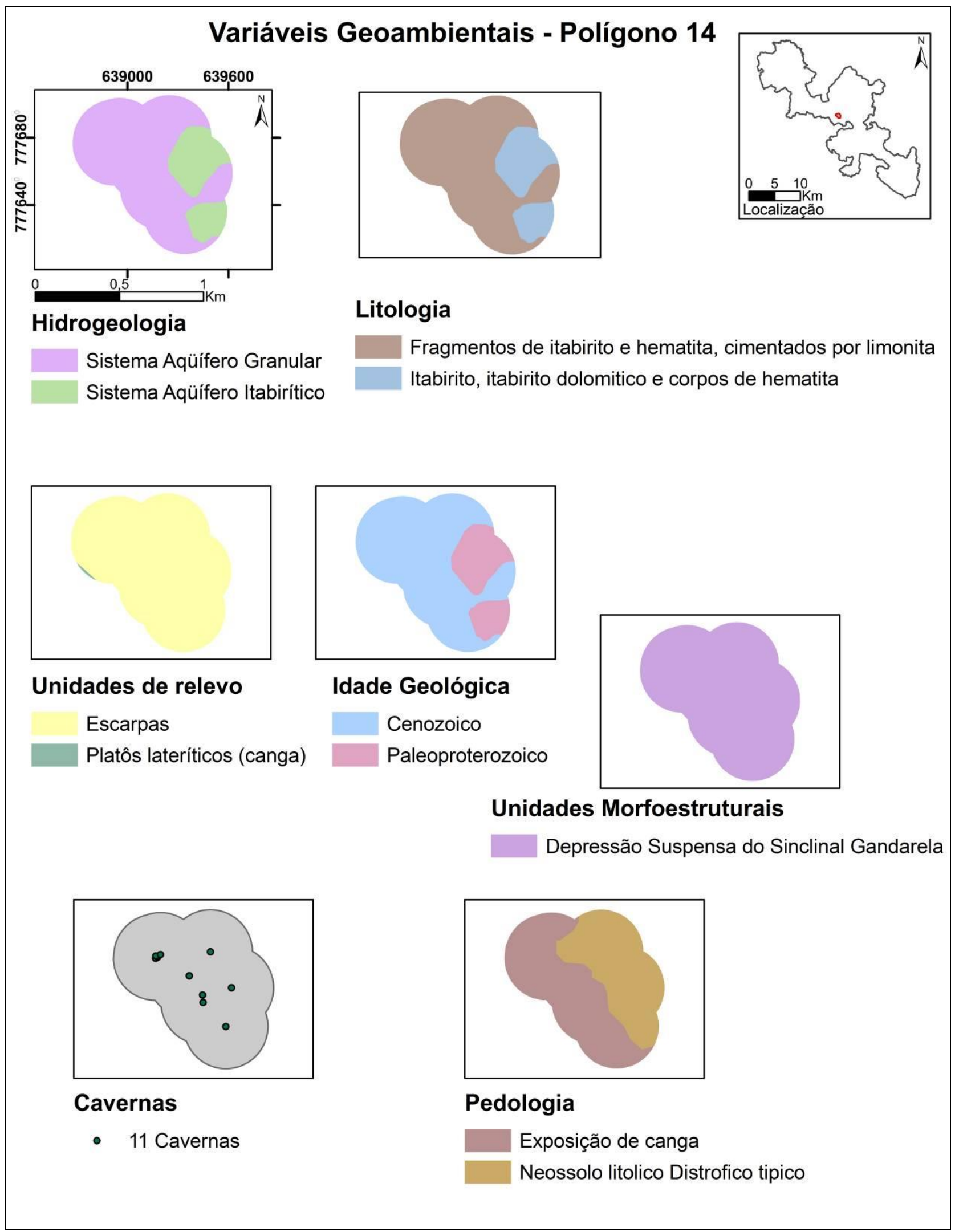

Figura 14- Variáveis geoambientais associadas ao Patrimônio Espeleológico no polígono 14 


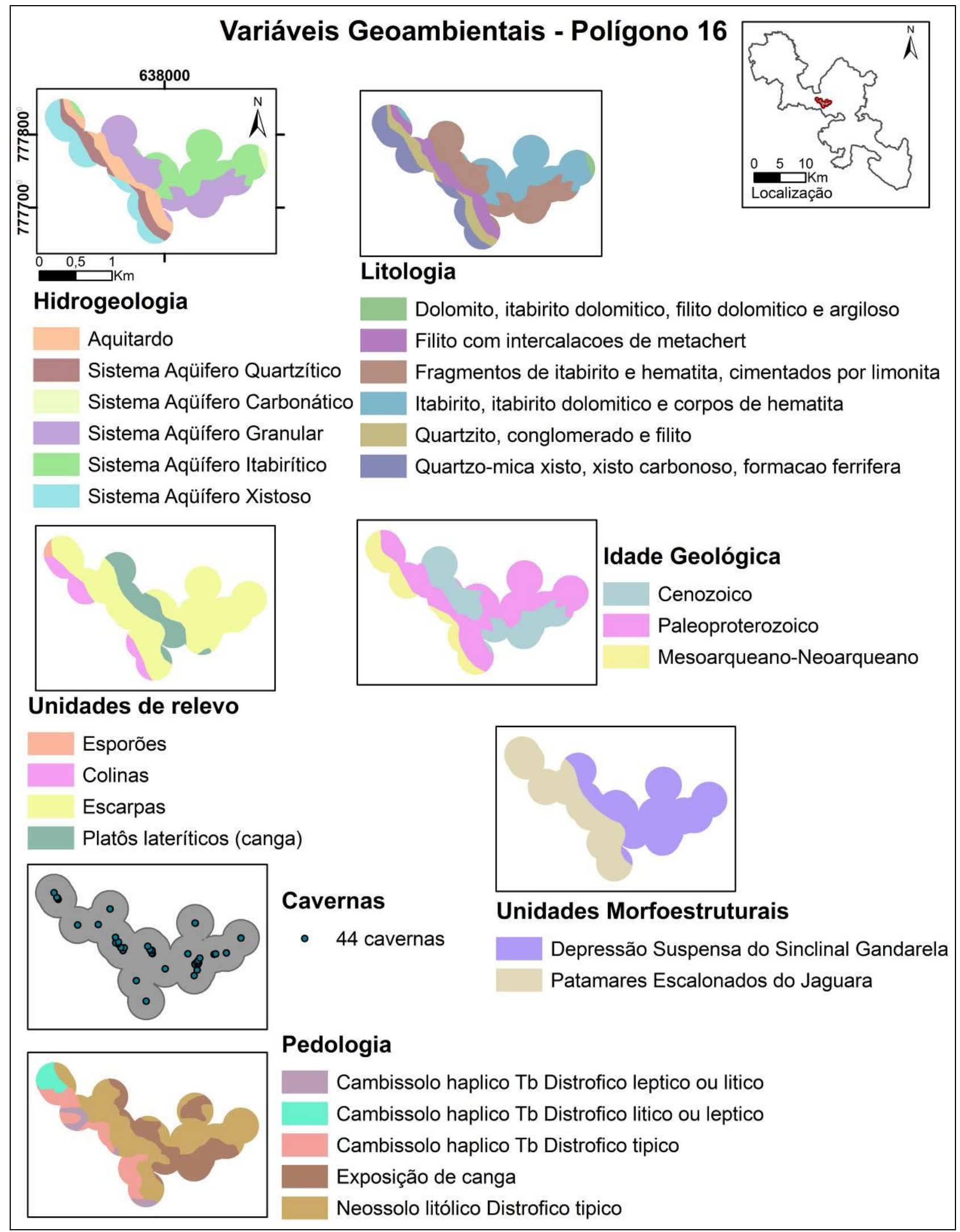

Figura 15- Variáveis geoambientais associadas ao Patrimônio Espeleológico no polígono 16 
A extensão da área favoreceu a ocorrência de grande variabilidade dos elementos geoambientais. Em sua face leste, o polígono está inserido na unidade morfoestrutural Depressão Suspensa do Sinclinal Gandarela (57\%). Três litotipos ligados às rochas ferruginosas estão presentes nesta face, com destaque para fragmentos de itabirito e hematita compacta, cimentados por limonita, de idade cenozóica, ocupando32\% da área do polígono e itabirito, itabirito dolomitico e corpos de hematita, do paleoproterozóico, ocupando $29 \%$. Em sua face oeste, está inserido na unidade morfoestrutural Patamares Escalonados do Jaguara (43\%). Nesta face encontram-se os litotipos quartzo-mica xisto, xisto carbonoso, formação ferrífera (15\%), filito com intercalações de metachert (13\%) e quartzito, conglomerado e filito (10\%), Neossolos litólicos (51\%) e exposição de canga (26\%) prevalecem na área, ocupando sua porção centro-leste. No restante da área, ocorrem os cambissolos háplicos $(23 \%)$.

Em sua face leste, apresenta altitudes em torno dos 1260 metros. Na porção central, estas atingem os 1.600 metros, condicionados pela cobertura de canga, e voltam a reduzir em direção a oeste, aproximando-se dos 1.400 metros.

Predomina vegetação herbácea, principalmente em sua parte central. Nas outras áreas, em meio à vegetação herbácea, podem ser encontrados fragmentos de porte arbóreo (Figura 16).



Figura 16- Vista parcial do polígono 16 (a), cobertura de canga associada a vegetação herbácea, com manchas de porte arbóreo; (b) detalhe do interior de uma das cavernas do polígono, desenvolvida sob a cobertura de canga.

Apresenta cavernas desenvolvidas em rochas siliciclásticas e ferruginosas, muitas das quais associadas à cobertura de canga. O polígono 25 está situado no município de Santa Bárbara. Apresenta 119 hectares, onde ocorrem 29 cavidades, resultando numa densidade de 0,24 cavernas por hectare. Suas variáveis geoambientais são apresentadas na figura 17.

Está totalmente inserido na unidade morfoestrutural Depressão Suspensa do Sinclinal Gandarela. Cerca de $90 \%$ da área apresenta o litotipo dolomito, itabirito dolomítico, filito dolomítico e argiloso, de idade paleoproterozóica, da formação Gandarela. Nesta área, são encontrados afloramentos dolomiticos de coloração acinzentada, nos quais foram identificados oncólitos (Figura 18) e estromatólitos colunares (RUCHKYS, 2007). 
O polígono é cortado no sentido norte-sul, em toda a sua extensão, pelo ribeirão Preto, bastante encaixado neste trecho. À esquerda da drenagem afloram os paredões dolomíticos, onde está localizada a maioria de suas cavernas, inclusive a cavidade GAND-0114, uma das maiores atualmente conhecidas no parque (Figura 18).

A cobertura de solos é constituída de cambissolo háplico, sustentando vegetação de porte arbóreo.

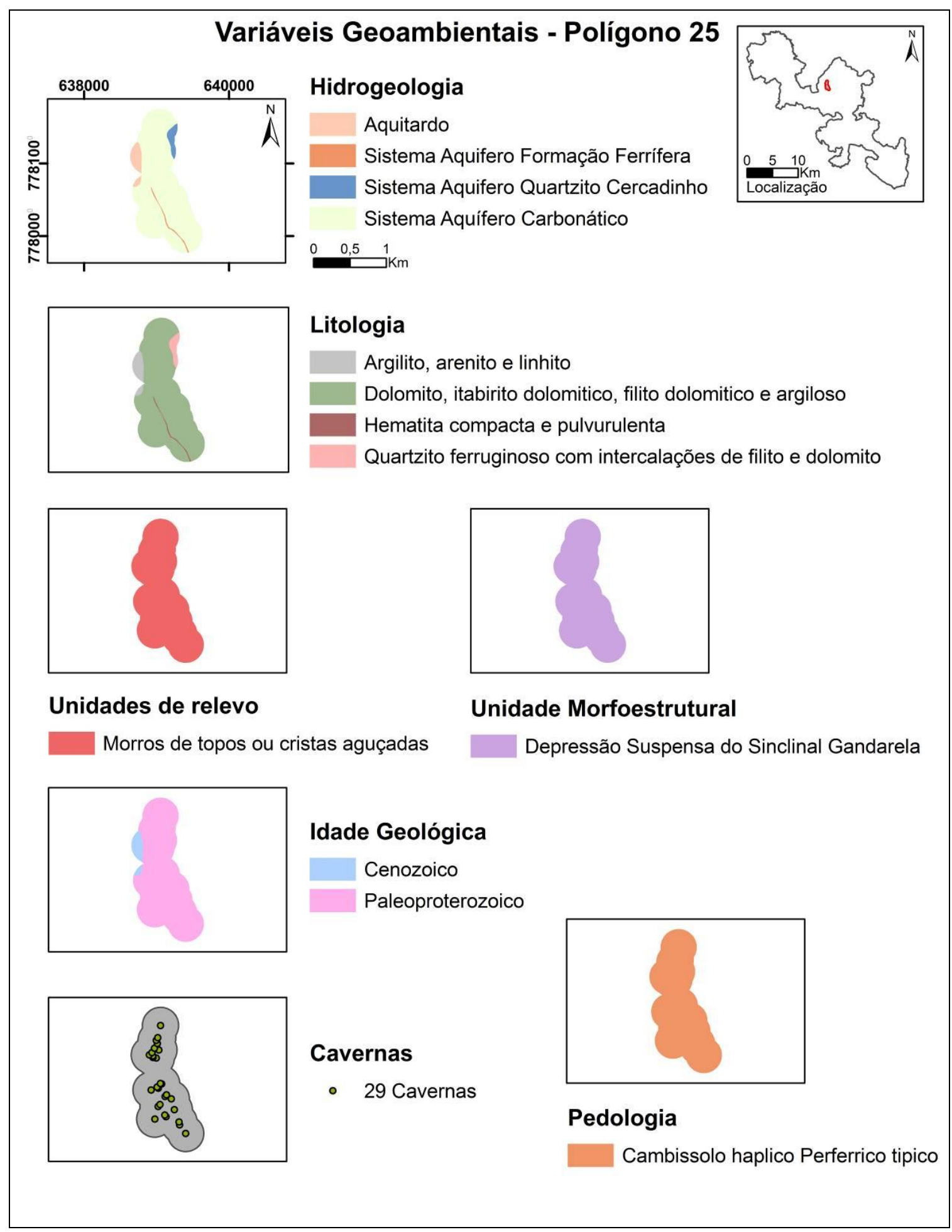

Figura 17- Variáveis geoambientais associadas ao Patrimônio Espeleológico no polígono 25 


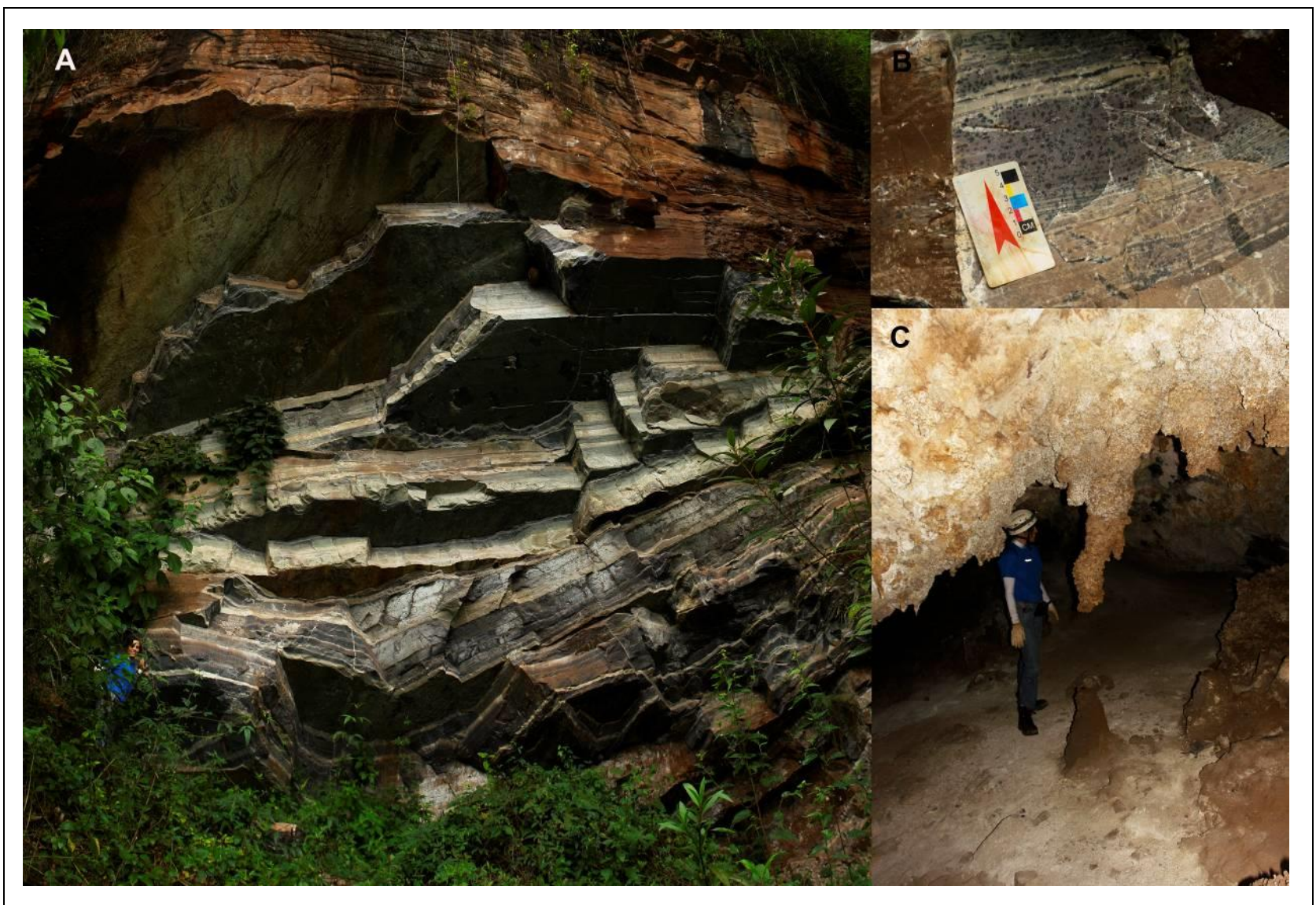

Figura 18 - Afloramento de dolomitos no polígono 25 (a), onde foram identificados oncoólitos (b). Detalhe de espeleotemas no interior da caverna GAND-0114 (c).

\section{CONSIDERAÇÕES FINAIS}

O estudo buscou caracterizar o entorno das cavidades naturais subterrâneas, especialmente em relação aos elementos do meio físico, utilizando técnicas de geoprocessamento.

O relevo movimentado associado a solos pouco desenvolvidos, especialmente cambissolos e neossolos, susceptíveis a erosão, sinalizam forte influência de processos morfogenéticos atuando na área. Por outro lado, a conservação da cobertura vegetal, garantida pela criação do parque, favorece os processos pedogenéticos, tanto em relação à manutenção quanto ao desenvolvimento das camadas de solo, contrapondo-se de forma dinâmica aos processos modificadores do relevo.

Entende-se, desta forma, que a área constitui um ambiente de equilíbrio frágil, onde alterações antrópicas podem resultar em efeitos deletérios em todos os elementos do ambiente, inclusive no patrimônio espeleológico.

O patrimônio espeleológico presente na área tem sua ocorrência imediata ou sua área de entorno associada a uma grande variabilidade de elementos da geodiversidade, principalmente em termos geológicos e geomorfológicos, mas também pedológicos. Esta riqueza reforça a importância das cavernas encontradas no Parque Nacional. Além disso, sinaliza vocação da unidade de conservação para atividades didáticas relacionadas a este patrimônio, haja vista a possibilidade de 
acessar cavidades desenvolvidas em diferentes litologias, associadas à ambientes diversos, com múltiplos processos genéticos, em uma mesma área.

\section{AGRADECIMENTOS}

Os autores agradecem a FAPEMIG pelo financiamento do Projeto APQ-02956-16: Sítios do geopatrimônio e da geodiversidade em geossistemas ferruginosos de Minas Gerais: inventariação, caracterização e propostas de geoconservação.

\section{REFERÊNCIAS}

BEATO, D. A. C.; MONSORES, A. L. M.; BERTACHINNI, A. C. Projeto APA Sul RMBH: Hidrogeologia, mapa hidrogeológico, escala 1:50.000. Belo Horizonte: SEMAD/CPRM. , 2005

BRASIL. PRESIDÊNCIA DA REPÚBLICA. Constituição da República Federativa do Brasil. publicada em 05 de outubro de 1988, out. 2008. Disponível em: <https://www.planalto.gov.br /ccivil_03/constituicao/constituicao.htm>. Acesso em: 02 mai. 2017.

BRASIL. PRESIDÊNCIA DA REPÚBLICA. Decreto $\mathbf{s} / \mathbf{n}^{\mathbf{0}}$, de 13 de outubro de 2014. Cria o Parque Nacional da Serra do Gandarela, localizado nos Municípios de Nova Lima, Raposos, Caeté, Santa Bárbara, Mariana, Ouro Preto, Itabirito e Rio Acima, Estado de Minas Gerais. 2014. Disponível em: <https://www.planalto.gov.br/CCIVIL_03/_Ato2011-2014/2014/Dsn/Dsn14013. htm>. Acesso em: 10 mar. 2016.

CECAV. Base de dados de cavidades naturais subterrâneas. Disponível em: <http://www.icmbio.gov.br/cecav/index.php?option=com_content\&view=article\&id=45\&Itemid=8 4 >. Acesso em: 13 jan. 2016.

CONAMA. Resolução $\mathbf{n}^{\mathbf{0}}$ 347, de 10 de setembro de 2004, que dispõe sobre a proteção do Patrimônio Espeleológico. . Brasília - DF: Conselho Nacional de Meio Ambiente. Disponível em: <http://www.mma.gov.br/port/conama/res> , 2004

CPRM. Projeto APA Sul RMBH: Estudos do meio físico. Belo Horizonte, MG: Companhia de Pesquisa de Recursos Minerais, 2005.

GRAY, M. Geodiversity: Valuing and Conserving Abiotic Nature. Chichester: John Wiley \& Sons Ltd. The Atrium, 2004. Disponível em: <http://books.google.com/books?id=LSB8A AAAQBAJ\&pgis=1>. Acesso em: 13 jan. 2016.

MANOSSO, F. C.; ONDICOL, R. P. Geodiversidade: Considerações Sobre Quantificação e Avaliação da Distribuição Espacial. Anuário do Instituto de Geociências, v. 35, n. 1, p. 90-100, 2012. Disponível em: 〈http://www.anuario.igeo.ufrj.br/2012_1/2012_1_90_100.pdf> Acesso em: 13 jan. 2016.

MEDINA, A. I. DE M.; DANTAS, M. E.; SAADI, A. Projeto APA Sul RMBH: geomorfologia, mapa geomorfológico, escala 1:50.000. Belo Horizonte: CPRM/EMBRAPA/SEMAD, 2005.

PEREIRA, E. O. Modelagem da geodiversidade na área de proteção ambiental sul da região 
metropolitana de Belo Horizonte - MG. 2013. Dissertação (Mestrado em Análise e Modelagem de Sistemas Ambientais) Departamento de Cartografia do Instituto de Geociências da Universidade Federal de Minas Gerais, 2013.

PFALTZGRAFF, P. A. DOS S.; CARVALHO, L. M. DE; RAMOS, M. A. B. Introdução. In: MACHADO, M. F.; SILVA, S. F. DA (Org.). . Geodiversidade do Estado de Minas Gerais. Programa Geologia do Brasil. Levantamentos da Geodiversidade. Minas Gerais: CPRM / Serviço Geológico do Brasil, 2010. p. 136.

PILÓ, L. B.; AULER, A. Introdução à Espeleologia. IV Curso de espeleologia e licenciamento ambiental. Brasília - DF: Instituto Chico Mendes de Conservação da Biodiversidade - ICMBio, 2010. p. 7-23. Dis'ponível em: <http://www.icmbio.gov.br/cecav/images/stories/downloads/ IV_Curso_de_Espeleologia_e_Licenciamento_Ambiental.pdf $>$ Acesso em: 13 jan. 2016.

REPÚBLICA, B. P. DA. Decreto $\mathbf{n}^{0} 99.556$, de $1^{\circ}$ de outubro de 1990 , que dispõe sobre a proteção das cavidades naturais subterrâneas existentes no Território Nacional e dá outras providências. . Brasília - DF: [s.n.]. , 1990. Disponível em: <http://www.planalto.gov.br /ccivil_03/decreto/ 1990-1994/d99556.htm> Acesso em: 20 jan. 2016

RUCHKYS, Ú DE A.; BITTENCOURT, J. DE S.; CARVALHO E BUCHMANN, F. S. DE. A paleotoca da Serra do Gandarela e seu potencial como geossítio do Geoparque Quadrilátero Ferrífero, Minas Gerais. Caderno de Geografia, v. 24, n. 42, p. 249-263, 2014.

RUCHKYS, Ú. DE A. Patrimônio Geológico e Geoconservação no Quadrilátero Ferrífero , Minas Gerais : Potencial para a Criação de um Geoparque da UNESCO. 2007. 211 f. Tese (Doutorado em Geologia) Instituto de Geociências da Universidade Federal de Minas Gerais, 2007.

SCHMITZ, P. I.; NOVASCO, R. V. Arqueologia no planalto: o uso do SIG na aplicação de análises espaciais dos sítios arqueológicos da localidade Boa Parada, Município de São José do Cerrito, SC. Revista do Museu de Arqueologia e Etnologia, v. 21, p. 167-183, 2011.

SERRANO, E.; RUIZ-FLAÑO, P. Geodiversity. A theoretical and applied concept. Geographica Helvetica, v. 62, n. 3, p. 140-147, 2007. 